\title{
Visitor Perceptions on the Impacts of Tourism Activities, Development and Infrastructure on the Environment of Perhentian Islands
}

\author{
M. Ramdas ${ }^{1}$, B. Mohamed ${ }^{2}$ \\ ${ }^{1,2}$ School of Housing, Building and Planning, Universiti Sains Malaysia, 11800 Penang, Malaysia \\ ${ }^{1,2}$ Sustainable Tourism Research Cluster, Universiti Sains Malaysia, 11800 Penang, Malaysia
}

\begin{abstract}
Tourism is one of the leading contributors to service industry in Malaysia and is gradually growing. The growth of this industry brings impact towards the environment, specifically islands. This study views into the tourists' perception on the impact of tourism activities, development and infrastructure to the environment of Perhentian Islands. A total number of 258 questionnaires were distributed to tourists in Perhentian Islands which is a popular tourist island destination in Malaysia. The results indicate that there is a significant number of moderate and high level of agreement that tourism activities, development and infrastructure are effecting the island's environment. It was also found that foreign tourist had significantly higher level of agreement for both variables than local tourist. However, it was found that there was no significant difference among gender for both variables. Establishing carrying capacity and embedding environmental education in sustainable tourism management would help broaden the perception of tourists.
\end{abstract}

\section{Introduction}

Tourism industry is one of largest service industry in Malaysia and continually growing. In 2012, the country received 4 to 6 billion tourists per year and is the 9th most visited country in the world which receives an income of RM 1 billion from foreign tourist per week. The industry is expected to grow further with a 36 million tourist arrival and 168 billion in income per year by 2020 [1]. The tourism industry is a major contributor to the foreign exchange, employment, payment for imported input goods while accumulating investments for new infrastructures [2-6].

The tourism industry is targeted to raise total Gross National Income contribution of RM67 billion to reach RM 104 billion by year 2020. Furthermore, the industry is targeting of employment offering opportunity amounted to 497,000 jobs [1]. The tourism industry has proven to be not only beneficiary toward the economic and social well-being but also contributes toward negative impacts towards a country $[2,7-10]$. Tourism activities have been identified to have a major negative impact towards the environment $[9,11-18]$.

The impact of tourism activities towards the environment spreads in a variety of components. The components that are directly affected by tourism activities include ecological resources, natural sights, air, energy and water consumption, and natural resources [2, 8-9, 15, 19-22]. The effect of tourism activities toward the environment has frequently been the essence of discussion in environmental summits. Environmental impacts from tourism activities was first highlighted in the Brundtland 
Commission 1987 where it was mentioned that any development although sufficient to the need of the present should not endanger the need of the future [16]. The next summit which brought forward the issue mitigating environmental impacts was the Rio Summit 1992 which introduced the concept of Local Agenda 21 [23].

Local Agenda 21 has identified various efforts from detailed tourism planning to the involvement of local community and tourists to ensure the sustainability of the environment due to tourism development. Torres-Delgado and Palomeque reviewed 16 summits or meetings that have included the concept of tourism that more environmentally conscious [24]. In recent development, the summit Rio +20 [25] discussed about the importance of protecting the environment throughout tourism development. In this summit, a report called 'The Future We Want' was produced. The report highlighted the involvement of the local community and the awareness of tourist as an important factor towards a tourism that considers the preservation of the environment for the future generation.

\section{Literature Review}

The intense and increased velocity of development of island tourism in Malaysia has adverse impact on its environment [26-29]. The most visible impact around the small islands would be to its marine biodiversity such as coral reef and fisheries. Apart from the usual activities such as snorkelling, diving, uncontrolled coral picking and swimming, other human activities also play a part damaging coral reefs. The accelerating construction of accommodation facilities after there was insurgence of tourist post Visit Malaysia Year, 1990 damaged abundance of coral reefs through sediments from the construction process. [30]. This added by the irresponsible behaviour of tourist such pulling out reefs when riding in a boat [31].

Tourism has also affected the abundance fisheries in the sea waters. Fishing which were once served as source living to the local communities has turned into a tourist recreation sport. The irresponsible attitude fishing resort owner who allows tourist to overexploit the source fisheries has resulted in the reduction in quantity and variety of fisheries. Dynamite blasting of fisheries by local fisherman to cater for the need of fishes for tourist adds on to existing damage [29, 32]. Excessive admittance tourists to an island with unmonitored activities could also bring possible damage natural forest trails exist. Soil erosion, imbalance to the habitats of flora and fauna and piling up of rubbish are some of effects that occur. The wildlife in the forest also disturbed by noise and air pollution that derives from tourists activities such open burning and use of motored vehicles. Moreover, the smuggling of endangered species would be the most feared damage to the wildlife. [33].

The impact of the water attribute of the small island was equally devastating as the coral reefs. The irresponsible action of local resorts owner of pumping sewage waste in to sea topped by excessive littering by tourist has deeply reduced the quality of the waters in small islands. Oil spillage and leakage from recreational add further to already existing contamination. [4, 28]. The worst part the impact is that severe contamination to this ecological attribute may need a long time for recovery or lead to extinction [33]. Beside seawater, groundwater in the surrounding area of the islands is also feeling the impact from the tourism industry. In certain islands, groundwater is the main source of freshwater and is high in demand especially by tourists. Hence, the increasing demand of groundwater will consequently lead to overexploitation of the resource. This may lead to shortage of fresh water on only for the tourism industry but also to the local residents. [29, 34].

From the discussion above, it is clear that tourism activities, development and infrastructure have adverse impact on the environment of the island. There is also an indication that tourists' behaviour plays an important part in aggravating the impact on the environment. In contrast, it was also found that tourists showed concern towards the environment is to ensure the sustainability of natural activities [4, 28]. However, there is no clear indication in recent studies whether the tourist have a clear perception towards the impact of tourism on the environment. 


\section{Aim and Objectives of the Study}

Hence, the aim of the study would be look at tourist perceptions impacts of tourism activities, development and infrastructure on the environment of Perhentian Islands. The specific objectives of this study would be to:-

i. The level of agreement of tourists on the impacts of tourism activities, development and infrastructure on the environment of Perhentian Islands.

ii. The difference in the level of agreement of tourists according to type of tourist and gender on the impacts of tourism activities, development and infrastructure Perhentian Islands.

\section{Methodology}

The main research method that was used is a quantitative design in the form of a survey. According to Best and Kahn, a survey usually involves acquiring a desired or undesired result [35]. In addition, the survey conducted in this research has two main purposes which are descriptive and explanatory [36]. The descriptive purpose of this study is to look at the level of agreement of the tourists on the impacts of tourism on the impact of tourism activities, development and infrastructure on the environment. The explanatory purpose would be to look at the difference between the level of agreement of the domestic and foreign tourist. A questionnaire was used an instrument to collect data for the study. The questionnaire that was used in this study consists of 18 questions on the impacts of tourism activities and development on the environment. Meanwhile, 11 questions were used on the impacts of infrastructure on the environment. A 5 point Likert scale was used to measure the level of agreement of the respondents on the environment. The scale that was used is " 5 " - strongly agree, " 4 " - agree, " 3 " - neither agree nor disagree, " 2 " - disagree and "1" - strongly disagree. The questionnaire was designed in 3 languages (Malay, Chinese and English) to accommodate both domestic and foreign tourists. The location that is chosen for this study is Perhentian Island. Perhentian Island was chosen because it has evolved into a major tourist attraction due to the development of world class facilities and scuba diving offerings [37-38 ]. Perhentian Island is located in the South China Sea $21 \mathrm{~km}$ of an East Coast state in Malaysia called Terengganu. The island consist two mains island known as Perhentian Besar (867 hectres) and Perhentian Kecil (524 hectres). It also consists of several small islands named Susu Dara, Seringgi and Rawa. The islands are blessed with rich and diverse species of coral reefs with about 127 types of fishes. During the peak season from July to October, it is believed that the hotels and chalets in the islands especially Perhentian Kecil have 100\% occupancy rate [3941]. Data obtained from the Marine Park Department of Malaysia showed that the number of tourists to Perhentian Island in 2012 is 36,976 domestic and 66,529 foreign visitors.

A simple random sampling was applied to selects to distribute the questionnaire. Data was collected from the respondents by directly administering the questionnaire to the respondents. The administration of the questionnaire was done in around the beaches in Perhentian Besar (72 respondents) and Perhentian Kecil (186 respondents). The data collection was done during the peak season (July to October 2012) of tourist to ensure more samples are available. The researcher distributed and gave some time for the respondent to fill in the questionnaire to avoid incomplete questionnaires. Data obtained was analysed using SPSS. A mean analysis was used to analyze the level of agreement of tourists. An independent sample t-test was conducted to analyse the difference of perception between tourists according to type of tourist and gender.

\section{Results and Discussion}

A total number of 258 tourists from Perhentian Islands were obtained as respondents. Although simple random sampling was applied, the tourists varied in the types of tourists and gender. There were 134 $(51.9 \%)$ local and $124(48.1 \%)$ foreign tourists as respondents. From the samples, total number of 181 $(70.2 \%)$ were male tourist and $77(29.8 \%)$ were female tourists Vargas-Sanchez et al included 
perception of tourist as an important variable in the model of explaining attitude towards tourism impacts [42]. A descriptive analysis would allow the researcher to analyse the perception of tourists.

Table 1. Tourists Perception on Tourism Activities and Development Environmental Impacts

\begin{tabular}{|c|c|c|}
\hline Level & Frequency & \% \\
\hline Low $(<3.56)$ & 92 & 35.7 \\
\hline Moderate $(3.57-3.94)$ & 90 & 34.9 \\
\hline High $(>3.95)$ & 76 & 29.4 \\
\hline
\end{tabular}

The level of tourists' perception in Table 1 indicates that the total percentage of respondents with moderate and high level of agreement stands at $64.3 \%$. This can interpreted that a large number tourists do agree that tourism activities and development have a significant impact on the physical environment of the island.

Table 2. Descriptive Analysis for Perceptions of Tourist on Tourism Activities and Development Environmental Impacts Items

\begin{tabular}{|c|c|c|c|}
\hline Items & Mean & SD & Level \\
\hline $\begin{array}{c}\text { Tourism activities (camping and hiking/forest recreation) } \\
\text { has affects on plants. }\end{array}$ & 3.86 & 0.875 & Moderate \\
\hline $\begin{array}{l}\text { Tourism activities (hotels/chalet service premises and } \\
\text { camping) contributes to compilation of solid waste in the } \\
\text { island which affect the plants. }\end{array}$ & 3.84 & 1.051 & Moderate \\
\hline $\begin{array}{l}\text { Disposal of solid and liquid waste from tourism activities } \\
\text { (hotel/chalet premises) effects the plants }\end{array}$ & 3.88 & .951 & Moderate \\
\hline $\begin{array}{l}\text { Tourism activities such as hiking/forest recreation and } \\
\text { camping affect the surrounding land of the island. }\end{array}$ & 3.50 & 1.060 & Low \\
\hline $\begin{array}{c}\text { Development and tourism activities effects land's } \\
\text { fertility }\end{array}$ & 3.66 & .945 & Moderate \\
\hline $\begin{array}{l}\text { Tourism activities cause erosion to the rocks and beaches } \\
\text { in the island. }\end{array}$ & 3.48 & 1.088 & Low \\
\hline $\begin{array}{l}\text { Land use for tourism development activities results in } \\
\text { loss in forest areas (Deforestation). }\end{array}$ & 3.75 & 1.007 & Moderate \\
\hline $\begin{array}{l}\text { Land use for tourism development activities results loss } \\
\text { in empty land. }\end{array}$ & 3.66 & 1.010 & Moderate \\
\hline $\begin{array}{c}\text { Improperly treated sewage waste from tourism premises } \\
\text { affect the environment. }\end{array}$ & 3.94 & 0.960 & Moderate \\
\hline $\begin{array}{c}\text { The environment of the island is effected by water-based } \\
\text { activities. }\end{array}$ & 3.91 & 0.976 & Moderate \\
\hline Living things in sea are affected by water pollution. & 4.06 & 0.934 & High \\
\hline $\begin{array}{c}\text { Smoke released by vehicles and open burning effect the } \\
\text { health and environment. }\end{array}$ & 3.98 & 0.976 & High \\
\hline Poor air quality affects tourism activities. & 3.85 & 0.965 & Moderate \\
\hline $\begin{array}{l}\text { Natural landscape in the island have changed compared } \\
\text { to before. }\end{array}$ & 3.52 & 0.901 & Low \\
\hline $\begin{array}{l}\text { Natural landscape should not be sacrificed to develop } \\
\text { accommodation premises and infrastructures because } \\
\text { there is no implication to the environment. }\end{array}$ & 3.07 & 1.305 & Low \\
\hline $\begin{array}{c}\text { Tourism development causes congestion and changes the } \\
\text { environment which affects tourism. }\end{array}$ & 3.55 & 0.950 & Low \\
\hline
\end{tabular}




\begin{tabular}{|c|c|c|c|}
\hline $\begin{array}{c}\text { Tourism activities and physical development affects the } \\
\text { habitat of the wildlife in the island. }\end{array}$ & 3.74 & 0.949 & Moderate \\
\hline $\begin{array}{c}\text { Biodiversity of living things are affected by tourism } \\
\text { activities (fishing and hunting) }\end{array}$ & 3.79 & 0.977 & Moderate \\
\hline
\end{tabular}

Overall, Table 2 shows that 11 out 18 items [61\%] are at moderate level. Meanwhile, items on water pollution and smoke released by vehicles and open burning have a high level of agreement. Where else, items erosion on rocks and beaches, natural landscape and congestion indicate a low level agreement.

Table 3. Level of Tourists Perception on Infrastructure Development Impact

\begin{tabular}{|c|c|c|}
\hline Level & Frequency & \% \\
\hline Low $(<3.82)$ & 86 & 33.3 \\
\hline Moderate $(3.83-4.09)$ & 96 & 37.2 \\
\hline High $(>4.10)$ & 76 & 29.5 \\
\hline
\end{tabular}

The level of tourists perception in Table 3 indicates that the total percentage of respondents with moderate and high level of agreement stands at $66.7 \%$. This can interpreted that a large number tourists do agree that tourism infrastructure development have a significant impact on the environment of the island.

Table 4. Descriptive Analysis for Perception of Tourist on Infrastructure Development Items

\begin{tabular}{|l|c|c|c|}
\hline \multicolumn{1}{|c|}{ Items } & Mean & SD & Level \\
\hline $\begin{array}{l}\text { Accommodation premises development and other } \\
\text { tourism structural development should be controlled } \\
\text { and monitored by authorities for sustainable } \\
\text { development. }\end{array}$ & 4.19 & 0.775 & High \\
\hline Tourism development effects the environment. & 4.08 & 0.824 & Moderate \\
\hline $\begin{array}{l}\text { Improper material [glass] used for buildings will } \\
\text { cause greenhouse effect [global warming] to the } \\
\text { environment. }\end{array}$ & 3.93 & 0.879 & Moderate \\
\hline $\begin{array}{l}\text { Tourism affects the upgrading of public facilities. } \\
\text { Improper sewage and solid waste management will } \\
\text { affect the island's tourism. }\end{array}$ & 3.86 & 0.790 & Moderate \\
\hline $\begin{array}{l}\text { Poor maintenance of public and tourist facilities will } \\
\text { affect the island's tourism industry }\end{array}$ & 3.90 & 0.799 & Moderate \\
\hline $\begin{array}{l}\text { Rural and small towns benefit from tourist activities } \\
\text { and development. }\end{array}$ & 4.02 & 0.756 & Moderate \\
\hline $\begin{array}{l}\text { Restoration and conservation is important for the } \\
\text { sustainability of the island destination [recycling, } \\
\text { turtle reproduction, beach cleaning etc] }\end{array}$ & 4.36 & 0.688 & High \\
\hline $\begin{array}{l}\text { Tourism development effects the natural and } \\
\text { manmade landscape in this island }\end{array}$ & 4.02 & 0.811 & Moderate \\
\hline $\begin{array}{l}\text { Development activities has "disturbed" the natural } \\
\text { environment. }\end{array}$ & 3.78 & 1.059 & Low \\
\hline $\begin{array}{l}\text { Tree cutting activities should not be done to build } \\
\text { tourist/residence facilities }\end{array}$ & 3.91 & 1.383 & Moderate \\
\hline
\end{tabular}


Overall, Table 4 shows that 8 out 11 items [73\%] are at moderate level. Meanwhile, items on control and monitoring of authorities on accommodation premises with restoration and conservation items have a high level of agreement. Where else, items on tourism development activities has "disturbed" the environment has low level of agreement.

Table 5. Difference in Perception Between Local and Foreign Tourists

\begin{tabular}{|c|c|c|c|}
\hline . & \multicolumn{2}{|c|}{ Physical Environment } & $\begin{array}{l}\text { Infrastructure } \\
\text { Development }\end{array}$ \\
\hline Domestic & & 3.6265 & 3.8433 \\
\hline Foreign & & 3.8311 & 4.0000 \\
\hline Mean Difference & & -2.0464 & -1.5745 \\
\hline \multirow{3}{*}{$\begin{array}{l}\text { Levene's } \\
\text { Test }\end{array}$} & $\mathrm{F}$ & 2.849 & 0.141 \\
\hline & Sig & 0.093 & 0.707 \\
\hline & $\mathrm{EVA}^{\mathrm{a}}$ & $\mathrm{X}$ & $\mathrm{X}$ \\
\hline \multirow{4}{*}{ T-test } & $\mathrm{T}$ & -2.846 & -2.618 \\
\hline & Df & 256 & 256 \\
\hline & Sig & 0.005 & 0.009 \\
\hline & $\mathrm{SD}^{\mathrm{b}}$ & $\sqrt{ }$ & $\sqrt{ }$ \\
\hline
\end{tabular}

*. Difference is significant at the 0.05 level [2-tailed];

${ }^{a}$ : Equal Variance Assumption; ${ }^{b}$ : Significant Difference

Table 5 shows the independent sample t-test analysis of the perception difference on variables between local and foreign tourists. The t-test indicates that there is significant difference between local and foreign tourists for both the variables. For both cases, foreign tourists have a higher level of agreement than local tourist.

Table 6. Difference in Perception Between Male and Female Tourists

\begin{tabular}{|c|c|c|c|}
\hline & \multicolumn{2}{|c|}{ Physical Environment } & Infrastructure Development \\
\hline \multicolumn{4}{|l|}{ Gender } \\
\hline Male & \multicolumn{2}{|c|}{3.7259} & 3.9247 \\
\hline Female & \multicolumn{2}{|c|}{3.7222} & 3.9055 \\
\hline Mean Difference & \multicolumn{2}{|c|}{0.046} & 0.1911 \\
\hline \multirow{3}{*}{$\begin{array}{l}\text { Levene's } \\
\text { Test }\end{array}$} & $\mathrm{F}$ & 0.525 & 0.359 \\
\hline & Sig & 0.470 & .287 \\
\hline & $\mathrm{EVA}^{\mathrm{a}}$ & $\mathrm{X}$ & $\mathrm{X}$ \\
\hline \multirow{4}{*}{ T-test } & $\mathrm{T}$ & 0.036 & 0.287 \\
\hline & Df & 256 & 256 \\
\hline & Sig & 0.963 & .774 \\
\hline & $\mathrm{SD}^{\mathrm{b}}$ & $\mathrm{X}$ & $\mathrm{X}$ \\
\hline
\end{tabular}

*. Difference is significant at the 0.05 level [2-tailed];

${ }^{a}$ : Equal Variance Assumption; ${ }^{b}$ : Significant Difference

Table 6 shows the independent sample t-test analysis of the perception difference on variables between male and tourists. The t-test indicates that there is no significant difference between male and female tourists for both the variable. 


\section{Conclusions \& Recommendations}

The study derived from the various impacts that tourism activities has brought on the environment of islands. Tourist behaviour play an important the aggravating the impact on the environment of islands. Past studies revealed that there was less focus in obtaining the perception of tourist on the impact brought on the environment. A survey using questionnaire was conducted to elicit the perception of tourist on the impacts of tourism on environment. Perhentian Islands which is a popular island destination in Malaysia was chosen as the location of the study. From the results that was obtained, it can be concluded that tourists believe that tourism activities, development and infrastructure have a significant effect on the environment. This brings to the conclusion that the tourists are very much aware and concerned towards the affect of tourism on the environment. Foreign tourist have a higher level of agreement on the impact of tourism activities and development on the environment that the domestic tourist. This can be concluded that foreign tourist are more aware and concerned on the impacts of tourism on the environment than domestic tourist.

As a recommendation, instilling tourists with environmental education could be a step to bring out positive actions. Ballantyne et al believed that environmental education could be bridge that helps to bring out a positive attitude from tourists towards the environment [43].Castellani \& Sala has identified that in measuring and assessing carrying capacity behavioural intention and characteristics of the tourists is an important factor to be considered [8]. Carrying capacity in tourism is the maximum number or threshold value which can be accepted or accommodated by a tourist destination while maintaining tourists satisfaction with reference to a standard of quality $[8,16,44]$. Hence, it is important to include environment education and carrying capacity in sustainable tourism management policy.

\section{Acknowledgement}

The funding for this project was made possible through the research grant obtained from the Ministry of Higher Education, Malaysia under the Long Term Research Grant Scheme 2011 [LRGS grant no: JPT.S (BPKI)2000/09/01/015Jld.4(67)

\section{References}

1. Prime Minister Dept of Malaysia. Economic Transformation Plan, (2010)

2. A.K.Bhattacharya, T.Sankar, Estimating the total carrying capacity of protected areas with respect to tourism activities - A case study of Bandhavgarh National Park, Madhya Pradesh, India, 1-10 (2000)

3. C.-C. Lee, C.-P. Chang, Tourism development and economic growth: A closer look at panels. Touri. Manage., 29, 1, 180-192 (2008) doi:10.1016/j.tourman.2007.02.013

4. K.T. Lee, \& S.S. Othman, Pertumbuhan dan Pelestarian Industri Eko-Pelancongan: Kajian Pulau-pulau Peranginan Sekitar Pantai Timur Sabah, Sosiohumanika 3, 2, 273-294 (2010).

5. M. Lozano-Oyola, F.J. Blancas, M. González, \& R. Caballero, Sustainable tourism indicators as planning tools in cultural destinations. Ecol. Indica. 18, 659-675 (2012)doi:10.1016/j.ecolind.2012.01.014

6. S.F. Schubert, , J.G. Brida,, \& W. Risso,. The impacts of international tourism demand on economic growth of small economies dependent on tourism. Touri. Manage., 32, 2, 377-385 (2012) doi:10.1016/j.tourman.2010.03.007

7. M. Badaruddin, P.M.S. Ahmad, J. Jamil, K.Y.Wong. Island Tourism In Malaysia: The Not So Good News. 1212-1219 (2003)

8. V. Castellani, \& S. Sala, Sustainable performance index for tourism policy development. Touri. Manage. 31 6, 871-880 (2010) doi:10.1016/j.tourman.2009.10.001 
9. H.C. Choi, \& E. Sirakaya, Sustainability indicators for managing community tourism. Touri. Manage., 27, 6, 1274-1289. (2005) doi:10.1016/j.tourman.2005.05.018

10. W. Gladstone, B. Curley, M.R. Shokri, Environmental impacts of tourism in the Gulf and the Red Sea. Mari. Pollu.Bulle. (2012) doi:10.1016/j.marpolbul.2012.09.017

11. K. Arrow, B. Bolin, R. Costanza, P. Dasgupta, C. Folke, C. Holling, B.O Jansson, Economic growth, carrying capacity, and the environment. Science New York, N.Y., 268, 5210, 520-1. (1995) doi:10.1126/science.268.5210.520

12. R. Buckley, Sustainable tourism: Research and reality. Ann of Touri. Res., 39, 2, 528-546. (2012) doi:10.1016/j.annals.2012.02.003

13. A. Holden, The Environment-Tourism Nexus. Ann of Touri. Res, 36, 3, 373-389. (2009) doi:10.1016/j.annals.2008.10.009

14. F. Kilipiris, S. Zardava, Developing Sustainable Tourism in a Changing Environment: Issues for the Tourism Enterprises [Travel Agencies and Hospitality Enterprises]. Proc. - Soc. \& Behav. Scie, 44, 44-52. (2012) doi:10.1016/j.sbspro.2012.05.003

15. K. Kim, M. Uysal, M.J. Sirgy, How does tourism in a community impact the quality of life of community residents? Touri. Manage. (2012) doi:10.1016/j.tourman.2012.09.005

16. S. Kostopoulou, I. Kyritsis, and A Tourism Carrying Capacity Indicator for Protected Areas, Anatolia: An Intern. J. of Touri. December, 37-41. (2012)

17. J.N. Silva, N. Ghilardi-Lopes, Indicators of the impacts of tourism on hard-bottom benthic communities of Ilha do Cardoso State Park (Cananéia) and Sonho Beach (Itanhaém), two southern coastal areas of São Paulo State (Brazil). Oce. \& Coast. Manage., 58, 1-8. (2012) doi:10.1016/j.ocecoaman.2011.12.009

18. F.J.G. Simón, Y. Narangajavana, D.P. Marqués, Carrying capacity in the tourism industry: a case study of Hengistbury Head. Touri. Manage., 25, 2, 275-283. (2004) doi:10.1016/S02615177[03]00089-X

19. G. Arabatzis, E.Grigoroudis, Tourists' satisfaction, perceptions and gap analysis: The case of Dadia-Lefkimi-Souflion National Park. For. Poli. \& Econs, 12, 3, 163-172. (2010) doi:10.1016/j.forpol.2009.09.008

20. K. Lei, S. Zhou, Per capita resource consumption and resource carrying capacity : A comparison of the sustainability of 17 mainstream countries. Ener. Pol., 42, 603-612. (2012) doi:10.1016/j.enpol.2011.12.030

21. H. Song, L. Dwyer, G. Li, Z. Cao, Tourism economics research: A review and assessment. Ann of Touri. Res, 39, 3, 1653-1682.(2012) doi:10.1016/j.annals.2012.05.023

22. Z. Tang, C.B. Shi, Z. Liu, Sustainable Development of Tourism Industry in China under the Lowcarbon Economy. Ener.Proce., 5, 1303-1307. (2011) doi:10.1016/j.egypro.2011.03.226

23. G.H. Cross, J.E. Johnson, A.E. Wood-arendt, The Role Of Outreach Education In Achieving The Role Of Outreach Education In Achieving : UNEP (2013)

24. A. Torres-Delgado, F. López Palomeque, The growth and spread of the concept of sustainable tourism: The contribution of institutional initiatives to tourism policy. Touri. Manage.Persp, 4, 110. (2012) doi:10.1016/j.tmp.2012.05.001

25. UNWTO, Turning One billion Tourists into One billion Dollars (2012)

26. H.S. Lim, F. Tan, M.Z. MatJafri, K. Abdullah, The environment study using Oceansat imagery over Penang Island. 2011 IEEE International Conference on Imaging Systems and Techniques, 65-69. (2011) doi:10.1109/IST.2011.5962224

27. M. Jaafar, S.A. Maideen, Ecotourism-related products and activities, and the economic sustainability of small and medium island chalets. Touri. Manage., 33, 3, 683-691. (2012) doi:10.1016/j.tourman.2011.07.011

28. M.A. Abdullah, Ali, N., R. Aznie, C. Rose, M. Fuad, M. Jali,. Industri pelancongan dan alam sekitar di Port Dickson : Menyorot titik keseimbangan antara permintaan dan penawaran, Goegrafia Online 7, 135-146. (2012)

29. L. Teh, A.S. Cabanban, Planning for sustainable tourism in southern Pulau Banggi: an assessment of biophysical conditions and their implications for future tourism development. J.of Enviro. Manage. 85, 4 (2007) 999-1008. doi:10.1016/j.jenvman.2006.11.005 


\section{ICTR}

30. P.K. Voon. Tourism and the Environment: The Case of Tioman Island, Malaysia, Islands of Malaysia : Issues and Challenges 151-170. (2000)

31. J.B. Fisher, R. Nawaz, R. Fauzi, F. Nawaz, E.S, Said Md Sadek, Z.Abd Latif, M. Lackett, . Balancing water, religion and tourism on Redang Island, Malaysia. Environmental Research Letters, 3, 2 (2008) 024005. doi:10.1088/1748-9326/3/2/024005

32. C.M. Hall,. Trends in ocean and coastal tourism: the end of the last frontier? Oce. \& Coas. Manage., 44, 9-10 (2001) 601-618. doi:10.1016/S0964-5691(01)00071-0

33. J.A Ibrahim, M.Z Ahmad .Penubuhan Geotaman Langkawi : Kesan Kepada Pelancongan Langkawi, 1-12. (2010)

34. S,M. Praveena, A.Z. Aris, M.H. Abdullah, K. Bidin,. Groundwater studies in tropical islands Sept, 200-204. (2010)

35. J.W. Best, J.V. Kahn, Research in Education. New York : Prentice Hall, (1998).

36. B. Taylor, G. Sinha, T. Ghoshal, Research Methodolgy. New Delhi : Prentice Hall (2006)

37. R. Aznie, Persepsi dan tingkat kepuasan pelancong di Pulau Pangkor, Geog. Onl. 155-168. (2011)

38. J. Mapjabil, M.P. Yusoh, R. Zainol, Implikasi sosioekonomi pembangunan pelancongan penyelaman skuba terhadap komuniti pulau di Malaysia: Satu tinjauan awal Socioeconomic implications of scuba diving tourism development on the island community of Malaysia: A preliminary observation, Geog. Onl., 5, 5, 26-38. (2012)

39. G.M.N. Islam, K.M. Noh, T.S. Yew, A.F.M. Noh, Assessing Environmental Damage to Marine Protected Area: A Case of Perhentian Marine Park in Malaysia. J. of Agri. Sci., 5, 8, 132-141. (2013) doi:10.5539/jas.v5n8p132

40. J.L. Salmond, The Social Relations Of Tourism On The Perhentian Islands . University of Kentucky Doctoral Dissertation (2010)

41. A. Hamzah, M.P. Hampton, Tourism Development and Change in Small Islands : Lessons from Perhentian Kecil Islands, Malaysia, 11(2011).

42. A. Vargas-Sánchez, N. Porras-Bueno, M.D.L.A. Plaza-Mejía, Explaining residents' attitudes to tourism. Ann of Touri. Res., 38, 2, 460-480. (2011) doi:10.1016/j.annals.2010.10.004

43. R. Ballantyne, J. Packer, L. Sutherland, Tourists' memories of wildlife tourism: Implications for the design of powerful interpretive experiences. Touri Manage, 32, 4, 770-779. (2011) doi:10.1016/j.tourman.2010.06.012

44. S. Bimonte, L.F. Punzo, The evolutionary game between tourist and resident populations and Tourist Carrying Capacity. Inter. $\mathrm{J}$ of Tech. and Globali., 3, 1, 73.(2007) doi:10.1504/IJTG.2007.012361 